\title{
FORECASTING PERMINTAAN POMPA AIR DANGKAL SHIMIZU MENGGUNAKAN METODE TIME SERIES
}

\author{
${ }^{1}$ Pajri Al Zukri, ${ }^{2}$ Syndi Nurina Widyaningrum, ${ }^{3}$ Qurrotul Aini \\ ${ }^{1,2,3}$ Sistem Informasi, Sains dan Teknologi, Universitas Islam Negeri Syarif Hidayatullah Jakarta \\ Jl. Ir. H. Djuanda No. 95, Ciputat, Tangerang Selatan, Banten, Indonesia 15412 \\ Email:pajri.alzukri17@mhs.uinjkt.ac.id, syndi.nurina17@mhs.uinjkt.ac.id,qurrotul.aini@uinjkt.ac.id
}

(Diterima:22 Desember 2019,direvisi:22 April 2020, disetujui:11 Mei 2020 )

\begin{abstract}
The amount of production of a shallow well PS 128 bit water pump indicates an imbalance with the number of requests, it indicates that the number of products that are in production is much more than the number of customer requests, causing high warehouse cost. Therefore, forecasting can be a solution to overcome the excess product in the warehouse and can help the company in determining the number of products that should be produced. PT Tirta Intimizu Nusantara, a division of Miyako Group, is one of the successful companies engaged in the home industry by producing electric water pump machines under the Shimizu brand. This research conducted the demand on PS 128 bit shallow water pump product by applying time series forecasting method namely Moving Average and Exponential Smoothing. The uses of both forecasting methods are to compare more accurately and find out the methods that can be used by the company in the next period using the POM QM Software for Windows. Based on the results of calculations, using POM QM Software for Windows that the most suitable method used in analyzing data with the smallest error rate is the Exponential Smoothing method with $\alpha=0.1$, which has a MAD value of 6421,412 and an MSE value of 59414,050. It concluded that the Exponential Smoothing method with $\alpha=0.1$ is an effective method used to predict the number of shallow water pump requests in the next period (month). The result of forecasting the number of shallow water pump requests in December 2019 using the Exponential Smoothing method with $\alpha=0.1$ is 44323.39. Thus, the researcher recommends that in the following year PT Tirta Intimizu Nusantara can use the Exponential Smoothing Method with $\alpha=0.1$ to perform demand forecasting.
\end{abstract}

Keywords: Forecasting, Exponential Smoothing, Moving Average, POM QM Software for Windows, Shimizu Shallow Water Pump.

\begin{abstract}
ABSTRAK
Jumlah produksi pompa air sumur dangkal PS 128 bit menunjukkan ketidak seimbangan dengan jumlah permintaan, hal itu menunjukkan bahwa jumlah produk yang di produksi lebih banyak daripada jumlah permintaan pelanggan, sehingga menyebabkan biaya gudang yang tinggi. Dengan adanya permasalahan tersebut peramalan dapat menjadi solusi untuk mengatasi kelebihan produk di gudang dan dapat membantu perusahaan dalam menentukan jumlah produk yang seharusnya diproduksi. PT Tirta Intimizu Nusantara merupakan divisi dari Miyako Group, adalah salah satu perusahaan yang sukses bergerak di bidang industri rumah tangga dengan memproduksi mesin pompa air listrik dengan merek Shimizu. Pada penelitian ini akan dilakukan peramalam permintaan pada produk pompa air dangkal PS 128 bit dengan menerapkan metode peramalan time series yaitu Moving Average dan Exponential Smoothing. Penggunaan kedua metode peramalan tersebut untuk membandingkan metode peramalan yang lebih akurat dan mengetahui metode yang dapat digunakan perusahaan pada periode selanjutnya dengan menggunakan Software POM QM for Windows. Berdasarkan hasil penghitungan, menggunakan Software POM QM for Windows bahwa metode yang paling sesuai digunakan dalam menganalisis data dengan memiliki tingkat kesalahan yang paling kecil adalah metode Exponential Smoothing dengan $\alpha=0,1$, yang memiliki nilai MAD sebesar 6421.412 dan nilai MSE sebesar 59414.050, Sehingga dapat disimpulkan bahwa metode Exponential Smoothing dengan $\alpha=0,1$ merupakan metode yang efektif digunakan untuk meramalkan jumlah permintaan pompa air dangkal periode (bulan) berikutnya. Hasil peramalan jumlah permintaan pompa air dangkal pada bulan Desember 2019 dengan menggunakan metode Exponential Smoothing dengan $\alpha=0,1$ adalah 44323.39. Sehingga, peneliti merekomendasikan pada tahun selanjutnya PT Tirta
\end{abstract}


Intimizu Nusantara dapat menggunakan Metode Exponential Smoothing dengan $\alpha=0,1$ untuk melakukan peramalan permintaan.

Kata Kunci: Forecasting, Exponential Smoothing, Moving Average, Software POM QM for Windows, Pompa Air Dangkal Shimizu.

\section{PENDAHULUAN}

PT Tirta Intimizu Nusantara merupakan divisi dari Miyako Group, adalah salah satu perusahaan yang sukses bergerak di bidang industri rumah tangga yang mulai berkembang sejak awal tahun 1995 dengan memproduksi mesin pompa air listrik dengan merek Shimizu [1]. PT Tirta Intimizu Nusantara merupakan salah satu perusahaan swasta yang terletak di Jl. Raya Serang KM.27, Sentul Jaya, Kec. Balaraja, Tangerang, Banten Kode Pos 15610 [2] pompa air yang di produksi perusahaan ini bervariasi yang dibedakan berdasarkan kegunaan dan kemampuan pompa air . Produk yang di produksi PT Tirta Intimizu Nusantara dikategorikan berdasarkan kedalaman sumur, yaitu Pompa Sumur Dangkal(Shallow Well Pump) dan Pompa sumur dalam(Deep Well Pump) yang masing-masing diklasifikasikan lagi sesuai dengan model yaitu gaya Italia dan gaya Jepang [1].
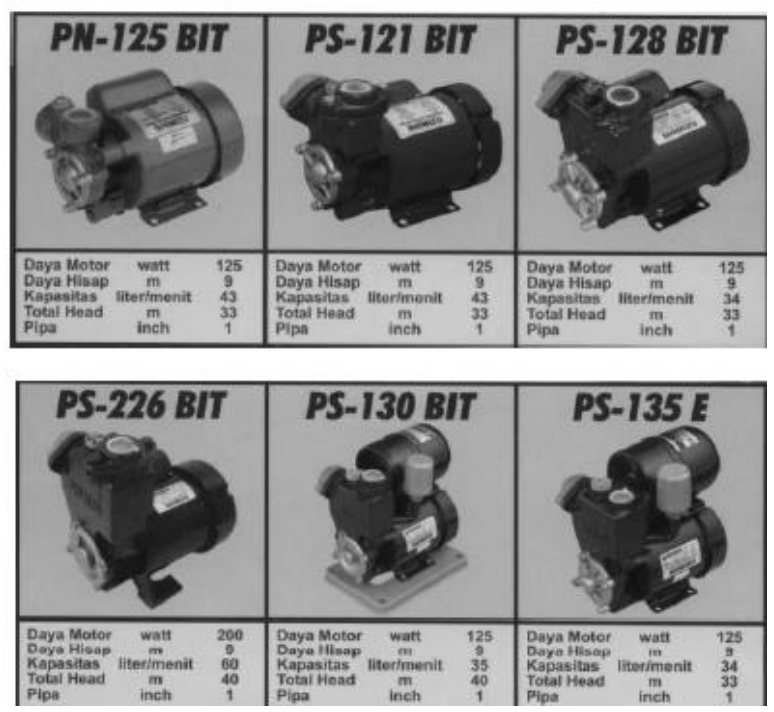

Gambar 1. Produk sumur dangkal gaya italia [1]

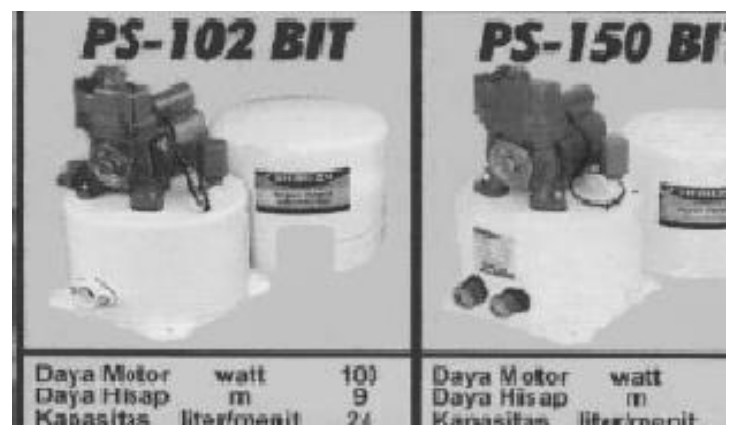

\section{Gambar 2 Produk pompa sumur dangkal gaya jepang [1]}

Produk pompa sumur dangkal merupakan produk paling laris untuk kategorinya, dikarenakan harga yang terjangkau dan cocok digunakan didaerah Asia, selain itu kategori pompa sumur dangkal merupakan inovasi baru PT Tirta Intimizu Nusantara yang memiliki daya hisap hingga 11 meter. PT. Tirta Intimizu Nusantara melakukan produksi produk tidak sesuai dengan permintaan konsumen sehingga, menimbulkan sisa produk yang berlebih di gudang. Hal ini menyebabkan biaya 
penyimpanan produk pun naik. Produk yang memiliki banyak permintaan adalah kategori pompa air sumur dangkal dengan tipe PS 128 bit gaya Italia seperti terlihat dalam Gambar 1. Berikut ini adalah data penjualan produk tipe PS 128 bit dalam periode Desember 2018 - November tahun 2019.

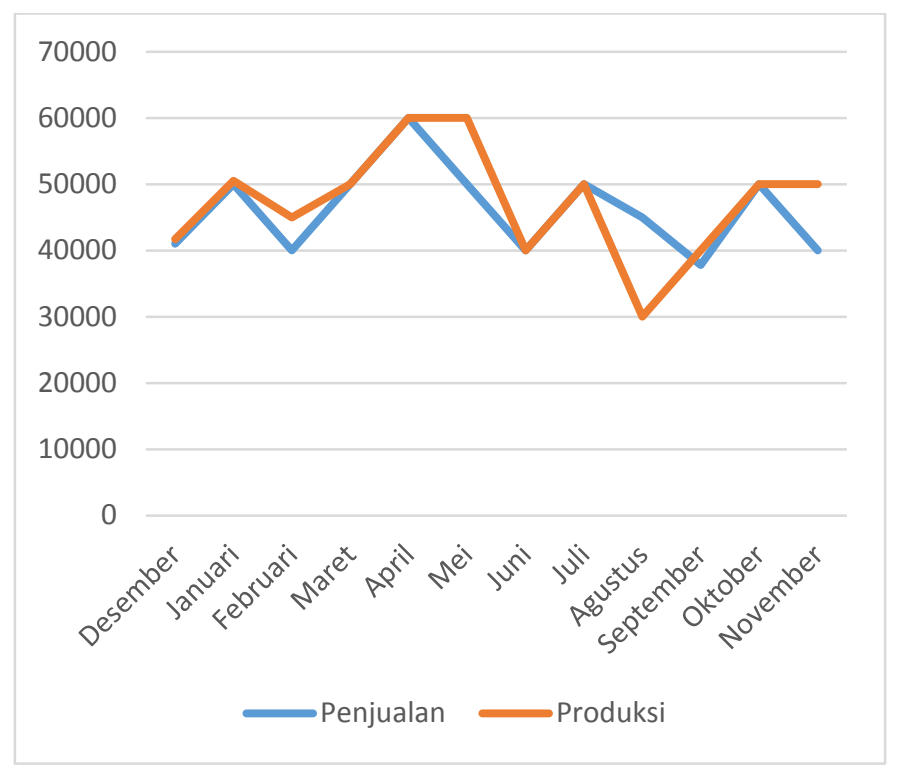

\section{Gambar 3 Data produksi dan penjualan produk ps 128 BIT}

Dalam grafik gambar 3 diatas, dapat di analisis bahwa jumlah produksi pompa air sumur dangkal PS 128 bit menunjukkan ketidakseimbangan dengan jumlah permintaan. Pada periode bulan Januari jumlah produksi 50.500 produk sedangkan jumlah produk yang terjual adalah 50.000 produk, hal itu menunjukkan bahwa jumlah produk di produksi lebih banyak daripada jumlah permintaan pelanggan, sehingga menyababkan biaya gudang yang tinggi. Dengan adanya permasalahan tersebut peramalan dapat menjadi solusi untuk mengatasi kelebihan produk di gudang [3]. Peramalan digunakan untuk tahapan awal dalam seluruh perencanaan produksi. Perencanaan dalam produksi pompa sumur air PS 128 bit perlu dilakukan dengan tepat dan benar sehingga tidak akan mengalami kelebihan banyak stock di gudang. Dan pada gambar dapat dilihat bahwa permintaan menurun, sehingga perusahaan harus dapat mengantisipasi keadaan itu dengan menggunakan peramalan untuk periode selanjutnya [4].

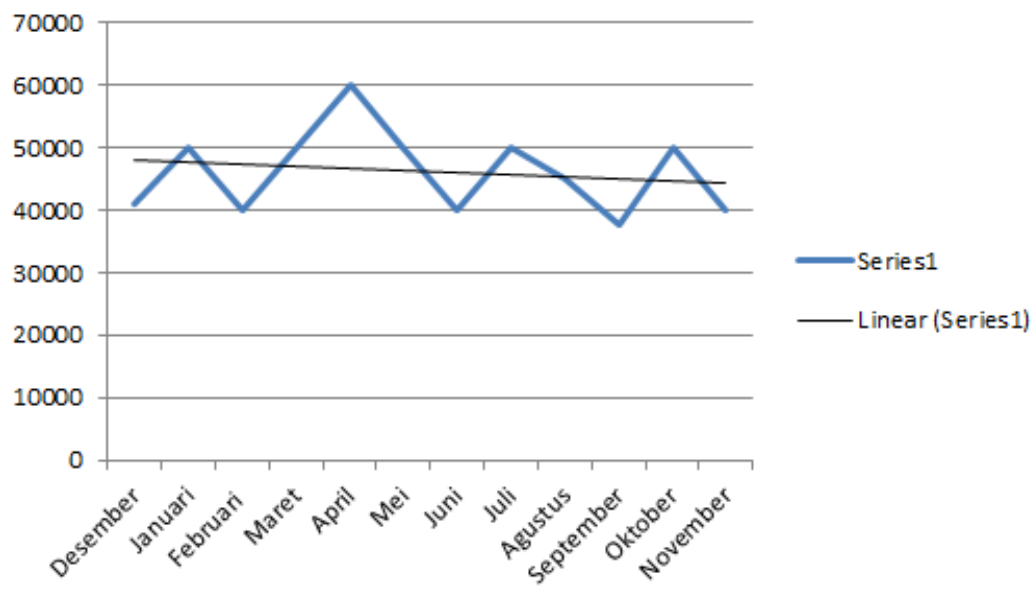

Gambar 4 Analisis trend permintaan 
Pada grafik gambar 4 diatas, menunjukkan analisis trend permintaan dari produk pompa sumur dangkal PS 128 bit pada bulan Desember 2018 sampai dengan November 2019.

Berdasarkan latar belakang diatas, maka masalah yang terdapat dalam peneltian ini adalah bagaimana peramalan produksi PS 128 bit pada periode selanjutnya dan apakah metode yang tepat digunakan untuk dapat memaksimumkan jumlah produksi. Mengacu pada [5] Metode time series terdiri dari beberapa metode, salah satunya adalah Moving Average atau rata-rata bergerak, regresi linear, dan Exponential Smoothing. Penggunaan metode time series untuk penelitian ini akan memberikan rekomendasi perusahaan, tujuan nya adalah untuk memperkirakan jumlah produk PS 128 bit yang akan diproduksi untuk periode selanjutnya sehingga perusahaan tidak akan mengalami kerugian, sehingga laba perusahaan pun dapat maksimal dan dapat membandingkan metode peramalan yang lebih akurat dan mendekati nilai aktual.

\section{TINJAUAN PUSTAKA}

Berdasarkan hasil penelitian [6], terhadap produk roti Sania Bakery yang dijadikan sebagai objek penelitian untuk meramalkan jumlah permintaan pada periode berikutnya. Dari pengolahan data diketahui jumlah permintaan terhadap produk Sania Bakery yaitu 1.893 .380 buah dilihat dari nilai SEE terkecil. Hasil ini didapatkan dari pengolahan data menggunakan metode Moving Average dan Weighted Moving Average.

Hasil penelitian [7], menggunakan metode peramalan menggunakan metode time series . Hasil penelitian menunjukkan kemungkinan kasus hipertensi untuk 36 bulan yang akan datang memiliki pola yang sama dengan data actual. Nilai MAPE untuk kasus hipertensi pada laki-laki adalah 25,71\% ; pada perempuan adalah 19,63\%; pada usia $\leq 44$ tahun $98,42 \%$; dan usia $\geq 45$ tahun adalah $13,98 \%$. Kesimpulan penelitian adalah kasus hipertensi di masa yang akan datang kemungkinan memiliki kemiripan kasus dengan pola data aktual.

Mengacu pada penelitian [8], melakukan penelitian peramalan terhadap produksi karet, hasil perhitungan peramalan dengan metode weighted moving average produksi karet mempunyai tingkat eror $2.52 \%$ yang tergolong kecil, sehingga tingkat ke akurasiannya tergolong besar.

Berdasarkan hasil penelitian [9], terhadap produk semen, nilai MSE menggunakan metode moving average memiliki nilai lebih rendah dibandingkan dengan metode exponential smoothing yaitu 5219,59 dan 20067,52, sehingga metode moving average merupakan metode yang lebih baik untuk digunakan dalam meramalkan penjualan semen untuk periode mendatang.

Mengacu pada hasil penelitian [10], Penggunaan metode time series pada peramalan untuk membandingkan metode peramalan yang lebih akurat dan mendekati nilai aktual. Berdasarkan hasil pengujian, bahwa metode yang paling sesuai digunakan dalam menganalisis data dengan memiliki tingkat kesalahan yang paling kecil adalah metode Exponential Smoothing $\alpha: 0,1$. Sesuai dengan hasil peramalan untuk tahun 2014 menggunakan moving average nilai pemintaan perak sebesar 1330 buah. Sedangkan untuk tahun 2014 dengan menggunakan exponential smoothing dengan nilai $\alpha: 0,1$, $\alpha: 0,5$ dan $\alpha: 0,9$ peramalannya masing-masing sebesar 1234, 1330 dan 1426.

Pada penelitian ini akan dilakukan peramalan menggunakan metode time series, yaitu Moving Average dan Exponential Smoothing, metode tersebut digunakan karena pada beberapa penelitian, metode tersebut akurat dalam melakukan peramalan. Kami melakukan penghitungan peramalan menggunakan Software POM QM for Windows, yang akan membantu dalam penghitungan secara otomatis menggunakan teknologi informasi yang sudah berkembang pesat sehingga tidak dihitung secara manual. Hasil yang diharapkan dari penelitian ini adalah merekomendasikan kepada PT Tirta Intimizu Nusantara terhadap metode yang tepat digunakan untuk melakukan peramalan.

\section{METODE PENELITIAN}

Metode yang digunakan dalam penelitian ini adalah Metode Kuantitatif. Metode kuantitatif adalah metode peramalan yang mengutamakan pola data historis yang dimiliki. Dalam peramalan menggunakan Metode peramalan time series merupakan metode yang digunakan untuk memprediksi masa depan dengan menggunakan data historis, time series melihat apa yang terjadi pada satu kurun waktu tertentu dengan menggunakan data masa lalu untuk meramalkannya. 
Metode yang digunakan untuk menghitung peramalan produksi PS 128 bit menggunakan jenis peramalan kuantitatif dari time series, yaitu metode Moving Average dan metode Exponential Smoothing .

\subsection{Moving Average}

Moving Average adalah suatu metode peramalan yang dilakukan dengan mengambil sekelompok nilai pengamatan, mencari nilai rata-rata tersebut sebagai ramalan untuk periode yang akan datang [11]. Metode Moving Average mempunyai karakteristik khusus yaitu :

a. Untuk menentukan ramalan pada periode yang akan datang memerlukan data historis selama jangka waktu tertentu. Misalnya, dengan 3 bulan Moving Average, maka ramalan bulan ke 5 baru dibuat setelah bulan ke 4 selesai/berakhir. Jika bulan Moving Averages bulan ke 7 baru bisa dibuat setelah bulan ke 6 berakhir.

b. Semakin panjang jangka waktu Moving Average, efek penghalusan semakin terlihat dalam ramalan atau menghasilkan Moving Average yang semakin halus.

Persamaan matematis single Moving Averages adalah sebagai berikut:

$$
M t=F t+1=\frac{Y t+Y t-1+Y t-2+\cdots+Y t-n+1}{n}
$$

Dengan, $\mathrm{M}_{\mathrm{t}}=$ Moving Average untuk periode $\mathrm{t}$, sedangkan $\mathrm{F}_{\mathrm{t}+1}=$ Ramalan Untuk Periode $\mathrm{t}+1$, $\mathrm{Y}_{\mathrm{t}}=$ Nilai Riil periode ke $\mathrm{t}$, dan $n=$ Jumlah batas dalam Moving Average.

\subsection{Exponential Smoothing}

Exponential Smoothing adalah suatu prosedur perbaikan terus-menerus pada peramalan terhadap objek pengamatan terbaru.

Selain itu untuk dapat mengetahui keakuratan antara kedua metode tersebut dapat dilihat melalui hasil hitung dalam kesalahan peramalannya yaitu tingkat kesalahan ramalan memberikan ukuran ketepatan dan ukuran untuk membandingkan metode-metode alternatif yang mungkin digunakan. Tingkat kesalahan peramalan dihitung dengan Mean absolute Deviation dan Mean Squared Error.

\subsection{Kesalahan Peramalan}

\subsubsection{Mean absolute Deviation (MAD)}

adalah rata-rata nilai absolut dari kesalahan meramal, dengan tidak menghiraukan tanda positif serta negatifnya.

$$
\boldsymbol{M A D}=\sum|\mathrm{At}-\mathrm{Ft}|
$$

Dengan MAD adalah Mean Absolute Deviation, $\sum$ adalah jumlah, sedangkan $\mathrm{A}_{\mathrm{t}}$ adalah nilai aktual perbulan dan $\mathrm{F}_{\mathrm{t}}$ adalah ramalan periode.

\subsubsection{Mean Squared Error ( MSE)}

adalah rata-rata perbedaan kuadrat antara nilai-nilai yang diramalkan dan nilai yang diamati MSE memberikan hukuman bagi kesalahan yang lebih besar, atau memperkuat pengaruh angka-angka kesalahan besar tetapi memperkecil angka. Kesalahan prakiraan yang lebih kecil dari suatu unit.

$$
\boldsymbol{M S E}=\sum \frac{(X t-F t)^{2}}{n}
$$

Dengan MSE adalah Mean Square Error, $\sum$ adalah Jumlah, sedangkan $F_{t}$ adalah Ramalan untuk periode $\mathrm{t}$, dan $\mathrm{X}_{\mathrm{t}}$ adalah Nilai aktual perbulan.

2.3.4 Mean Absolute Percentage Error (MAPE) adalah perhitungan perbedaan antara data asli dengan data hasil peramalan. Perbedaan tersebut di absolutkan, kemudian dihitung ke dalam bentuk persentase terhadap data asli. Hasil persentase tersebut kemudian didapatkan nilai mean-nya. Suatu model mempunyai kinerja sangat bagus jika nilai MAPE berada di bawah $10 \%$, dan mempunyai kinerja bagus jika nilai MAPE berada di antara $10 \%$ dan 20\% [12].

$$
\mathbf{M A P E}=\sum_{i-1}^{n} \frac{\left|X_{t}-F_{t}\right|}{n} \times 100 \%
$$


Dengan $X_{t}$ adalah Data History atau data actual pada period ke- $t, F_{t}$ adalah data hasil ramalan pada periode ke- $t$, sedangkan $\mathrm{n}$ adalah Jumlah data yang digunakan, dan $\mathrm{t}=$ periodeke- $t$

\section{HASIL DAN PEMBAHASAN}

Dalam melakukan peramalan menggunakan data masa lalu yaitu data permintaan tahun 2019 dalam 1 periode, ini akan digunakan untuk melakukan peramalan periode selanjutnya.

Peramalan dengan menggunakan metode time series dilakukan dengan menggunakan Software POM QM for Windows di dapatkan nilai sebagai berikut [13]:

\subsection{Moving Average}

Perhitungan peramalan permintaan Pompa Dangkal Desember 2019 dengam menggunakan Moving Average, menggunakan length 2 adalah sebagai berikut [14]:

\section{Tabel 1 Hasil Forecasting mengguanakan Moving Average}

\begin{tabular}{lll}
\hline & Demand $(\mathrm{y})$ & Forecast \\
\hline December & 41000 & \\
\hline January & 50000 & \\
\hline February & 40000 & 45500 \\
\hline March & 50000 & 45000 \\
\hline April & 60000 & 45000 \\
\hline May & 50000 & 55000 \\
\hline June & 40000 & 55000 \\
\hline July & 50000 & 45000 \\
\hline August & 45000 & 45000 \\
\hline September & 37800 & 47500 \\
\hline October & 50000 & 41400 \\
\hline November & 40000 & 43900
\end{tabular}

Pada tabel 1 diatas, peramalan dengan menggunakan metode Moving Average dengan length 2, artinya peramalan dilakukan dengan melihat data mulai dari bulan Februari karena di beri length 2. Pada bulan Desember 2019 peramalan permintaan pompa sumur dangkal PS 128 bit adalah 43900 buah/produk.

\subsection{Exponential Smoothing}

Metode Exponential Smoothing akan diterapkan pada perhitungan dalam menentukan permintaan periode selanjutnya. Dalam peramalan ini menggunakan Software POM QM for Windows yang akan dicoba menggunakan alpha $(\alpha)$ secara acak sebagai nilai bobot yaitu, $\alpha=0,1, \alpha=0,5$, dan $\alpha=0,9$ sebagai berikut :

Exponential Smoothing $\alpha=0,5$

\subsubsection{Exponential Smoothing $\alpha=0,1$}

Tabel 2. Hasil Forecasting menggunakan Exponential Smoothing $\alpha=0,1$

\begin{tabular}{lll}
\hline & Demand $(\mathrm{y})$ & Forecast \\
\hline December & 41000 & \\
\hline January & 50000 & 41000 \\
\hline February & 40000 & 41900 \\
\hline March & 50000 & 41710 \\
\hline April & 60000 & 42539 \\
\hline May & 50000 & 44285.1 \\
\hline June & 40000 & 44856.59 \\
\hline July & 50000 & 44370.93 \\
\hline August & 45000 & 44933.84 \\
\hline September & 37800 & 44940.45 \\
\hline October & 50000 & 44226.41 \\
\hline November & 40000 & 44803.77
\end{tabular}


Pada tabel 2, adalah hasil perhitungan forecasting menggunakan software POM QM dengan metode Exponential Smoothing dengan $\alpha=0,1$. Jika dilihat maka forecast yang diusulkan pada tiap bulannya terdapat pada kolom ke-3. Sehingga, dapat disimpulkan bahwa untuk peramalan permintaan bulan Desember 2019 sebesar 44803.77 buah/produk.

\subsubsection{Exponential Smoothing $\alpha=0,5$}

Tabel 3. Hasil Forecasting menggunakan Exponential Smoothing $\alpha=0,5$

\begin{tabular}{lll}
\hline & Demand $(\mathrm{y})$ & Forecast \\
\hline December & 41000 & \\
\hline January & 50000 & 41000 \\
\hline February & 40000 & 45500 \\
\hline March & 50000 & 42750 \\
\hline April & 60000 & 46375 \\
\hline May & 50000 & 53187.5 \\
\hline June & 40000 & 51593.75 \\
\hline July & 50000 & 45796.88 \\
\hline August & 45000 & 47898.44 \\
\hline September & 37800 & 46449.22 \\
\hline October & 50000 & 42124.61 \\
\hline November & 40000 & 46062.3
\end{tabular}

Pada tabel 3, adalah hasil perhitungan forecasting menggunakan software POM QM dengan metode Exponential Smoothing dengan $\alpha=0,5$. Jika dilihat maka forecast yang diusulkan pada tiap bulannya terdapat pada kolom ke-3. Sehingga, dapat disimpulkan bahwa untuk peramalan permintaan bulan Desember 2019 sebesar 46062.3 buah/produk.

\subsubsection{Exponential Smoothing $\alpha=0,9$}

Tabel 4. Hasil Forecasting menggunakan Exponential Smoothing $\alpha=0,9$

\begin{tabular}{lll} 
& Demand $(\mathrm{y})$ & Forecast \\
\hline December & 41000 & \\
\hline January & 50000 & 41000 \\
\hline February & 40000 & 49100 \\
\hline March & 50000 & 40910 \\
\hline April & 60000 & 49091 \\
\hline May & 50000 & 58909.1 \\
\hline June & 40000 & 50890.91 \\
\hline July & 50000 & 41089.09 \\
\hline August & 45000 & 49108.91 \\
\hline September & 37800 & 45410.89 \\
\hline October & 50000 & 38561.09 \\
\hline November & 40000 & 48856.11
\end{tabular}

Pada tabel 4, adalah hasil perhitungan forecasting menggunakan software POM QM dengan metode Exponential Smoothing dengan $\alpha=0,9$. Jika dilihat maka forecast(peramalan) yang diusulkan pada tiap bulannya terdapat pada kolom ke-3. Sehingga, dapat disimpulkan bahwa untuk peramalan permintaan bulan Desember 2019 sebesar 48856.11 buah/produk.

\subsection{Rekapitulasi hasil perhitungan error dan pemilihan error terkecil}

Perhitungan error dilakukan dengan metode MAD dan MSE. Data yang digunakan dan dibandingkan untuk nilai error adalah data tahun 2019. Hal ini dikarenakan data Tahun 2019 merupakan data yang lengkap dengan nilai aktual dan nilai peramalan [10]. 

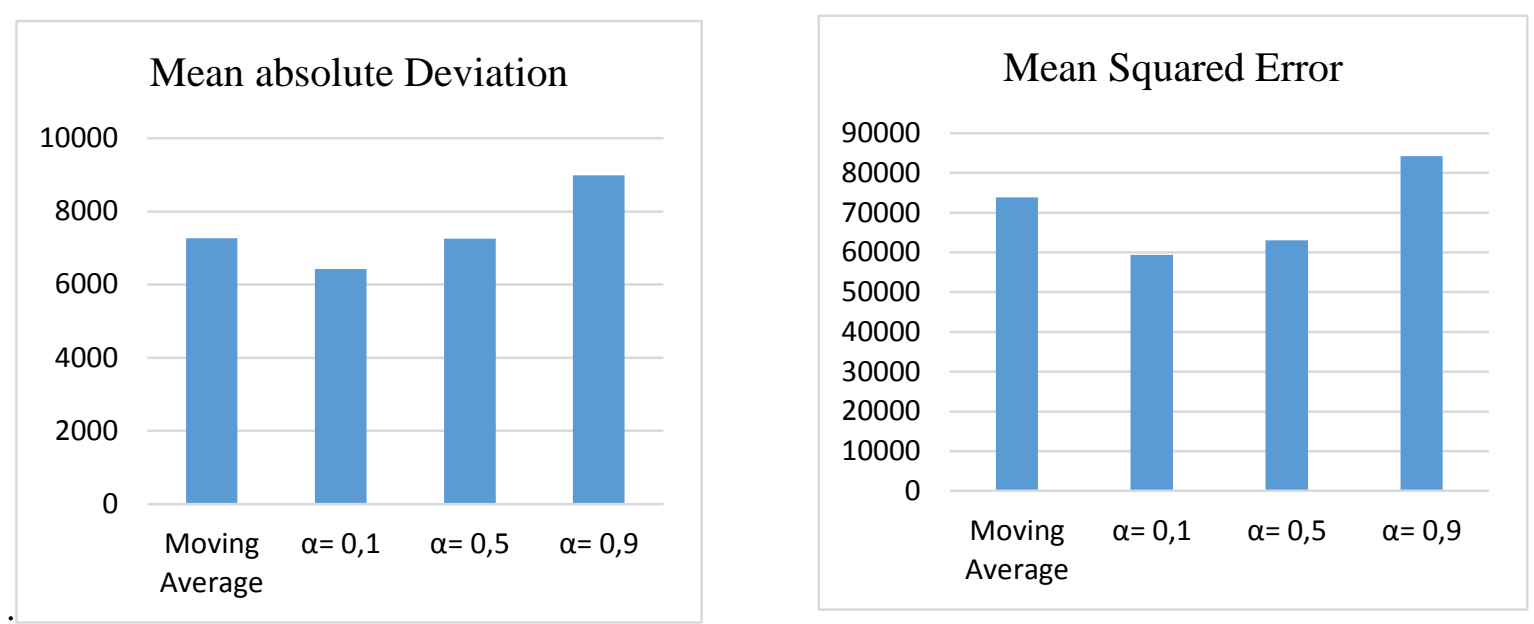

Tabel 6. Hasil rekapitulasi perhitungan error

\begin{tabular}{|c|c|c|c|c|}
\hline Metode & MAD & MSE & MAPE & Jumlah peramalan permintaan \\
\hline $\begin{array}{l}\text { Moving } \\
\text { Average }\end{array}$ & 7.270 & 73.850 .990 & $15.89 \%$ & 45000 \\
\hline $\begin{array}{l}\text { Exponentic } \\
\text { Smoothing }\end{array}$ & & & & \\
\hline$\alpha=0,1$ & 6.421 .412 & 59.414 .050 & $13.26 \%$ & 44323.39 \\
\hline$\alpha=0,5$ & 7.258 .611 & 63.061 .620 & $15.72 \%$ & 43031.15 \\
\hline$\alpha=0,9$ & 8.984 .066 & 84.265 .530 & $19.48 \%$ & 40885.61 \\
\hline
\end{tabular}

Berdasarkan perhitungan ramalan permintaan Pompa Air Dangkal dengan metode Moving Average length 2 pada Desember 2019 sebesar 45000, dengan Mean Absolute Deviation $=7.270$ dan Mean Squared Error $=73.850 .990$, sedangkan perhitungan ramalan permintaan Pompa Air Dangkal dengan metode Exponential Smoothing $\alpha=0,1$ pada Desember 2019 sebesar 44323.39, dengan Mean Absolute Deviation $=6.421 .412$ dan Mean Squared Error $=59.414 .050$, sedangkan perhitungan ramalan permintaan Pompa Air Dangkal dengan metode Exponential Smoothing $\alpha=0,5$ pada Desember 2019 sebesar 43031.15, dengan Mean Absolute Deviation $=7.258 .611$ dan Mean Squared Error $=63.061 .620$, sedangkan perhitungan ramalan permintaan Pompa Air Dangkal dengan metode Exponential Smoothing $\alpha=0,9$ pada tahun 2020 sebesar 40885.61, dengan Mean Absolute Deviation $=8.984 .066$ dan Mean Squared Error $=84.265 .530$.

\section{KESIMPULAN}

Berdasarkan hasil perhitungan metode moving average dan Exponential Smoothing dapat dilihat bahwa nilai Mean absolute Deviation (MAD) dan Mean Squared Error (MSE) terkecil berada pada metode Exponential Smoothing dengan $\alpha=0,1$, yang memiliki nilai MAD sebesar 6421.412 dan nilai MSE sebesar 59414.050, Sehingga dapat disimpulkan bahwa metode Exponential Smoothing dengan $\alpha=0,1$ merupakan metode yang efektif digunakan untuk meramalkan jumlah permintaan pompa air dangkal periode (bulan) berikutnya. Hasil peramalan jumlah permintaan pompa air dangkal pada bulan Desember 2019 dengan menggunakan metode Exponential Smoothing dengan $\alpha=0,1$ adalah 44323.39. Peneliti merekomendasikan pada tahun selanjutnya perusahaan dapat menggunakan Metode Exponential Smoothing dengan $\alpha=0,1$ untuk melakukan peramalan.

\section{REFERENSI}

[1] A. Lutfi, "Analisis dan Perancangan Sistem E-SCM pada PT Tirta Intimizu Nusantara," Pelayanan Kesehat., vol. 2013, pp. 3-13, 2010.

[2] MDMedia, "Tirta Intimizu Nusantara PT," 2018. [Online]. Available: https://yellowpages.co.id/bisnis/tirta-intimizu-nusantara-pt-1. 
[3] R. T. Amira Herwindayani, Wiwik Anggraeni, "Pembuatan Aplikasi Pendukung Keputusan Untuk Peramalan Persediaan Bahan Baku Produksi Plastik Blowing dan Inject Menggunakan Metode ARIMA (Autoregressive Integrated Moving Average) Di CV. Asia," J. Tek. POMITS, vol. 3, no. 2, p. A-169, 2014.

[4] H. Yulius and D. D. Putra, "Pengendalian Perencanaan Produksi Premium Dan Harga Pesan Crude Oil Ekonomis Menggunakan Metode Peramalan Dan Economic Order Quantity ( Studi Kasus Di PT Pertamina RU II Dumai)," J. Edik Inf., pp. 220-230.

[5] A. Nurlifa and S. Kusumadewi, "Sistem Peramalan Jumlah Penjualan Menggunakan Metode Moving Average Pada Rumah Jilbab Zaky," INOVTEK Polbeng - Seri Inform., vol. 2, no. 1, p. 18, 2017.

[6] I. P. Henny Yulius1, Yadi Prawinata2, "Peramalan Penjualan Pada Usaha Kecil Menengah ( UKM ) Roti Sania Dengan Menggunakan Program POM QM,” J. Edik Inform., vol. 1, pp. 6469.

[7] N. G. Putri, Y. T. Herawati, and A. Ramani, "Peramalan Jumlah Kasus Penyakit Hipertensi Di Kabupaten Jember Dengan Metode Time Series," J. Heal. Sci. Prev., vol. 3, no. 1, pp. 39-46, 2019.

[8] A. Nasution, "Forecasting Produksi Karet Menggunakan Metode Weighted Moving Average," Semin. Nas. R. 2018, vol. 9986, no. September, pp. 133-138, 2018.

[9] R. Rahmadayanti, B. Susilo, and D. Puspitaningrum, "Perbandingan Keakuratan Metode Autoregressive Integrated Moving Average (Arima) dan Exponential Smoothing pada Peramalan Penjualan Semen di PT Sinar Abadi," J. Rekursif, vol. 3, no. 1, pp. 23-36, 2015.

[10] N. L. A. K. Yuniastari and I. W. W. Wirawan, "Peramalan Permintaan Produk Perak Menggunakan Metode Simple Moving Average Dan Single Exponential Smoothing," Sist. dan Inform. STIKOM Bali, pp. 97-106, 2016.

[11] R. Rachman, "Penerapan Metode Moving Average Dan Exponential Smoothing Pada Peramalan Produksi Industri Garment," J. Inform., vol. 5, no. 2, pp. 211-220, 2018.

[12] I. S. J. Djie, "Analisis Peramalan Penjualan dan Penggunaan Metode Linear Programming dan Decision Tree Guna Mengoptimalkan Keuntungan pada PT Primajaya Pantes Garment," The Winners, vol. 14, no. 2, p. 113, 2013.

[13] G. L. lahera Hera-Fuentes, R. Torres-Ruiz, and J. D. Rada-Noriega, "Seducción y aversión: Factores de susceptibilidad y desincentivo al inicio del consumo de tabaco entre adolescentes en Bolivia," Salud Publica Mex., vol. 59, pp. S73-S79, 2017.

[14] Afni Sahara, "Sistem Peramalan Persediaan Unit Mobil Mitsubishi Pada Pt . Sardana Indah Berlian Motor Dengan," Maj. Ilm. Inf. dan Teknol. Ilm. ISSN 2339-210X, pp. 1-7, 2013. 